\title{
SIKAP KONSUMEN DAN WILLINGNESS TO PAY (WTP) PADA PRODUK BUAVITA ROYALE
}

\author{
CONSUMER ATTITUDE AND WILLINGNESS TO PAY (WTP) IN BUAVITA ROYALE PRODUCTS
}

\author{
Diana Sugiyanthi")1, Rita Nurmalina ${ }^{* *}$, dan Tanti Novianti***) \\ *) Sekolah Bisnis, IPB University \\ Jl. Padjajaran, Bogor, Indonesia 16151, Indonesia \\ ${ }^{* *}$ Departemen Agribisnis, Fakultas Manajemen dan Ekonomi, IPB University \\ Jl. Agatis, Kampus IPB Dramaga, Bogor 16680, Indonesia \\ ${ }^{* * *}$ Departemen Ilmu Ekonomi, Fakultas Manajemen dan Ekonomi, IPB University \\ Jl. Agatis, Kampus IPB Dramaga, Bogor 16680, Indonesia
}

\begin{abstract}
This study aims to determine consumer attitudes towards Buavita Royale products, analyze the factors that influence willingness to buy consumer (WTB), and measure the maximum value of willingness to pay consumers' (WTP) towards Buavita Royale products. The results of research on consumer attitudes toward Buavita Royale products using the Fishbein analysis method found that overall obtained an assessment of 291.37 so that consumers remain willing to consume, buy and have the desire to pay for Buavita Royale products. Based on the research results of consumer attitudes with the Importance Performance Analysis (IPA) approach to find out what strategies can be carried out by the company is found packaging design variables, benefits, tastes, consumer experience and reputation of PT Unilever needs to be maintained, but the variables; recognition of product brands, availability in the market, and outstanding prices need to be improved. Factors that influence willingness to buy consumers'Buavita Royale products found that the variable that has a significant effect on consumers' desire to pay for Buavita Royale products is that the prices of products circulating in the market today are not a problem for respondents, so product prices tend to increase consumers' willingness to buy. Consumers also have a positive attitude towards Buavita Royale products. The maximum value of the consumer's WTP against Buavita Royale products for $250 \mathrm{ml}$ size with an average value of maximum price of Rp8,226 while for the size of 1,000 ml consumers are willing to pay the maximum price with an average price of Rp30,019.
\end{abstract}

Keywords: fishbein, IPA, consumer attitudes, willingness to pay, willingness to buy

\begin{abstract}
Abstrak: Penelitian ini bertujuan mengetahui sikap konsumen terhadap produk Buavita Royale, menganalisis faktor-faktor yang mempengaruhi willingness to buy (WTB) konsumen terhadap produk Buavita Royale, serta mengukur besarnya nilai maksimum willingness to pay (WTP) konsumen terhadap produk Buavita Royale. Hasil dari penelitian mengenai sikap konsumen terhadap produk Buavita Royale dengan menggunakan metode analisis Fishbein ditemukan bahwa secara keseluruhan mendapatkan penilaian 291,37 sehingga konsumen tetap bersedia untuk mengonsumsi, membeli dan memiliki keinginan untuk membayar produk Buavita Royale. Berdasarkan hasil penelitian sikap konsumen dengan pendekatan Importance Performance Analysis (IPA) untuk mengetahui strategi apa saja yang dapat dilakukan oleh perusahaan adalah ditemukan variabel desain kemasan, manfaat, rasa, pengalaman konsumen serta reputasi PT Unilever perlu dipertahankan, akan tetapi variabel; pengenalan akan merek produk, ketersediaan dipasaran, serta harga yang beredar perlu diperbaiki. Faktor-faktor yang memengaruhi WTB konsumen terhadap produk Buavita Royale ditemukan bahwa variabel yang berpengaruh signifikan terhadap keinginan konsumen untuk membayar produk Buavita Royale adalah harga produk yang beredar dipasaran saat ini tidak menjadi persoalan bagi responden sehingga harga produk cenderung meningkatkan kesediaan konsumen untuk membeli. Konsumen pun memiliki sikap yang positif terhadap produk Buavita Royale. Besarnya nilai maksimum WTP konsumen terhadap produk Buavita Royale untuk ukuran $250 \mathrm{ml}$ dengan nilai rata-rata harga maksimum sebesar Rp8.226 sedangkan untuk ukuran $1.000 \mathrm{ml}$ konsumen bersedia membayar harga maksimum dengan harga rata-rata Rp30.019.
\end{abstract}

Kata kunci: fishbein, IPA, sikap konsumen, willingness to pay, willingness to buy

\footnotetext{
${ }^{1}$ Corresponding author:

Email: deejay.diana11@gmail.com
} 


\section{PENDAHULUAN}

Badan Pusat Statistik (BPS) (2014) menyatakan bahwa bahwa presentase konsumsi sayur dan buah masyarakat Indonesia per kapita dari tahun 2010-2014 mengalami fluktuasi. Hampir seluruh penduduk Indonesia sebanyak 97,92\% mengkonsumsi sayur, sedangkan 3 dari 4 penduduk Indonesia mengkonsumsi buah. Semakin banyaknya orang yang bekerja dan memiliki waktu singkat, membuat minat konsumen lebih kepada sesuatu yang serba instan dan cepat. Sebesar $48 \%$ dari total belanja middle class income di Indonesia memilih produk Fast Moving Consumer Goods (FMCG) terutama makanan dan minuman termasuk Minuman dalam kemasan (ready to drink (RTD)).

Pola hidup masyarakat Indonesia kini memiliki kesadaran terhadap pola hidup sehat yaitu dengan mengkonsumsi buah dan sayur. Buah dan sayur bersifat perishable, sehingga dibutuhkan inovasi untuk dapat mengkonsumsi buah dan sayur yang awet namun kandungan gizinya tetap sama seiring dengan meningkatnya konsumsi buah dan sayur dari tahun ke tahun. Singkatnya waktu yang dimiliki masyarakat karena banyaknya jumlah masyarakat yang bekerja pun menjadi permasalahan yang harus diselesaikan. Salah satu upayanya adalah membuat produk RTD yang telah dilakukan oleh Buavita. Namun, dengan harga Buavita yang beragam, khususnya produk Buavita Royale yang lebih mahal dibandingkan dengan produk lainnya yang sejenis dipasaran. Berdasarkan latar belakang tersebut, penelitian ini bermaksud untuk mengetahui bagaimana sikap konsumen terhadap produk Buavita Royale serta seberapa besar minat konsumen untuk membayar harga maksimum terhadap produk Buavita Royale.

Menurut Mowen dan Minor (2002) mendefinisikan sikap sebagai afeksi atau perasaan untuk atau terhadap sebuah rangsangan. Sehingga sikap konsumen terhadap Buavita Royale yaitu sebuah produk minuman sari buah dan sayur dalam kemasan ditengah maraknya persaingan produk sejenis menjadi sesuatu yang menarik untuk diteliti lebih lanjut. Secara umum, nilai ekonomi didefinisikan sebagai pengukuran jumlah maksimum seseorang yang ingin mengorbankan barang dan jasa untuk memperoleh barang dan jasa lainnya. Konsep ini disebut keinginan membayar (Willingness to Pay (WTP)).
Berikut disajikan tinjauan penelitian terdahulu yang terkait dengan penelitian ini. Penelitian Rusniati (2014) dengan judul Analisis sikap konsumen terhadap minuman teh dalam kemasan karton merek teh kotak di Banjarmasin bertujuan untuk menganalisis atributatribut produk teh dalam kemasan karton dengan melakukan teknik purposive sampling. Hasil penelitian menunjukan bahwa atribut rasa, kepekatan, aroma, kemasan dan harga berpengaruh positif terhadap sikap konsumen. Penelitian yang berjudul Fruits and vegetables market in Romania: better understand consumers' preferences yang dilakukan oleh Andreea dan Ion (2015), menggunakan metode analisis teknik investigasi terstruktur, menyebutkan bahwa 94\% responden mengkonsumsi sayuran dan buah-buahan yang diawetkan, yang memvalidasi asumsi yang dibuat, yaitu $80 \%$ dari responden mengkonsumsi atau melakukan pembelian sayuran yang diawetkan, 90\% responden mengkonsumsi atau melakukan pembelian terhadap buah-buahan yang diawetkan. Kriteria yang paling penting untuk memilih sayuran dan buahbuahan dalam kaleng berupa komposisi, rasa dan asal atau produsen, serta harga yang termurah.

Faktor-faktor yang memengaruhi WTP konsumen berdasarkan studi dari Narine et al. (2015) mengusulkan bahwa lokasi tempat tinggal, tingkat pendidikan, rentang pendapatan, dan persepsi konsumen mengenai manfaat kesehatan secara signifikan mempengaruhi WTP konsumen terhadap produk organik. Studi yang dilakukan Kalashami et al. (2012) melakukan penelitian dengan variabel pendidikan, tingkat konsumsi perminggu, sikap dan manfaat. Bahwa dengan adanya peningkatan pendidikan konsumen sebesar 10\% peningkatan pendidikan, konsumsi per minggu, sikap dan manfaat yang didapat dari mengonsumsi ayam organik, maka akan meningkatkan WTP per 1 kilogram ayam organik masing-masing sebesar 9,5\%, 4,4\%, dan $32 \%$. Peningkatan yang paling mempengaruhi kenaikan WTP adalah apabila konsumen telah merasakan keuntungan atau manfaat yang didapat dari mengonsumsi ayam organik. Tanner dan Kast (2003) serta Laroche et al. (2001) juga menunjukan hasil yang sama bahwa konsumen bersedia membayar lebih untuk produk organik.

Hermawan dan Yusran (2015) menyatakan bahwa sikap merupakan salah satu determinan yang dipengaruhi oleh kesadaran kesehatan dan pada akhirnya mempengaruhi kesediaan membayar produk. Bukan hanya sikap, namun pengetahuan dan kebiasaan (familiaritas) 
dapat pula mempengaruhi konsumsi dan berpengaruh terhadap WTP konsumen (Diaz et al. 2012). Faktorfaktor lain yang juga turut berkontribusi terhadap keinginan orang untuk membeli minuman kemasan dengan harga premium menentukan sikap konsumen terhadap pembelian suatu produk (Anselmsson et al. 2014). Secara keseluruhan perbedaan penelitian terdahulu dengan penelitian yang dilakukan adalah pada Objek penelitian dan tempat penelitian, metode penelitian, jenis dan objek penelitian, serta metode penelitian.

Tujuan penelitian ini adalah 1) menganalisis sikap konsumen terhadap produk Buavita Royale; 2) merumuskan strategi dengan pendekatan IPA; 3) menganalisis faktor-faktor yang memengaruhi willingness to buy; 4) mengukur besarnya nilai maksimum willingness to pay konsumen terhadap produk Buavita Royale. Ruang lingkup penelitian ini adalah menganalisis sikap konsumen pada produk Buavita Royale di Kota Bogor. Adapun batasan usia responden penelitian adalah usia 18 sampai 30 tahun pada usia remaja dan konsumen yang telah bekerja.

\section{METODE PENELITIAN}

Data dalam penelitian ini adalah data primer dan sekunder. Data primer, yaitu berupa hasil kuesioner. Data sekunder, yaitu studi pustaka atau jurnal, tesis atau disertasi maupun buku teks. Data yang diperoleh selanjutnya dianalisis secara deskriptif kuantitatif. Analisis data kualitatif dilakukan menggunakan model Fishbein, Analisis IPA, Analisis Regresi Logistik, dan Analisis Regresi.

\section{Model Sikap Multiatribut Fishbein}

Fishbein dan Ajzen (dalam Kristianto dan Paulus, 2011), sikap merupakan presdisposisi (keadaan mudah terpengaruh) yang dipelajari untuk menanggapi secara konsisten terhadap suatu objek, baik dalam bentuk tanggapan positif maupun tanggapan negatif. Model ini menggambarkan bahwa sikap konsumen terhadap suatu produk atau merek ditentukan oleh dua hal, yaitu kepercayaan terhadap suatu atribut (komponen Bi), dan evaluasi pentingnya atribut dari produk tersebut (komponen Ei). Model ini digambarkan dengan formula sebagai berikut:

$$
\text { Ao }=\sum \text { ni }=1(\text { bi . ei })
$$

Keterangan: Ao (sikap terhadap suatu objek); Bi (kekuatan kepercayaan/keyakinan bahwa objek memiliki atribut i); Ei (evaluasi konsumen terhadap atribut i); $\sum$ ni $=1$ (penjumlahan dari sejumlah atribut yang dimiliki objek). Pada penelitian ini, terdapat sepuluh jenis atribut yang digunakan untuk menilai sikap produk Buavita Royale. Deskripsi atribut tersebut terlihat pada Tabel 1.

Tabel 1 Atribut sikap dan deskripsi atribut penelitian

\begin{tabular}{|c|c|c|}
\hline Variabel & Kode & Atribut Variabel \\
\hline \multirow[t]{3}{*}{ Kemasan } & $\mathrm{X} 1$ & Desain kemasan sangat menarik \\
\hline & $\mathrm{X} 2$ & Logo mudah ditemukan \\
\hline & $\mathrm{X} 3$ & Warna kemasan sangat menarik \\
\hline \multirow[t]{4}{*}{ Manfaat } & $\mathrm{X} 4$ & Bermanfaat bagi kesehatan tubuh \\
\hline & $\mathrm{X} 5$ & $\begin{array}{l}\text { Manfaat yang didapat berbentuk } \\
\text { intangible }\end{array}$ \\
\hline & $\mathrm{X} 6$ & Dapat melepas dahaga \\
\hline & $\mathrm{X} 7$ & $\begin{array}{l}\text { Manfaat berpengaruh positif bagi } \\
\text { tubuh }\end{array}$ \\
\hline \multirow[t]{2}{*}{ Merek } & $\mathrm{X} 8$ & Merek popular bagi siapapun \\
\hline & X9 & $\begin{array}{l}\text { Merek mempunyai reputasi yang } \\
\text { sangat baik }\end{array}$ \\
\hline \multirow{3}{*}{$\begin{array}{l}\text { Pengetahuan } \\
\text { produk }\end{array}$} & $\mathrm{X} 10$ & Reputasi PT Unilever sangat baik \\
\hline & $\mathrm{X} 11$ & $\begin{array}{l}\text { Motivasi PT. Unilever sangat jelas } \\
\text { dan visioner }\end{array}$ \\
\hline & $\mathrm{X} 12$ & $\begin{array}{l}\text { Konsumen memiliki pengalaman } \\
\text { yang menyenangkan }\end{array}$ \\
\hline \multirow[t]{2}{*}{ Rasa } & $\mathrm{X} 13$ & Memiliki banyak varian rasa \\
\hline & $\mathrm{X} 14$ & Rasa enak sekali \\
\hline Promosi & $\mathrm{X} 15$ & Besarnya intensitas promosi \\
\hline \multirow{3}{*}{$\begin{array}{l}\text { Ketersediaan } \\
\text { produk }\end{array}$} & $\mathrm{X} 16$ & Mudah ditemukan dipasaran \\
\hline & $\mathrm{X} 17$ & $\begin{array}{l}\text { Konsumen memiliki waktu untuk } \\
\text { membeli }\end{array}$ \\
\hline & $\mathrm{X} 18$ & $\begin{array}{l}\text { Konsumen bisa dengan cepat } \\
\text { menemukan produk karena dekat } \\
\text { dengan rumah/kantor }\end{array}$ \\
\hline \multirow[t]{2}{*}{ Harga } & X19 & Harga murah \\
\hline & $\mathrm{X} 20$ & $\begin{array}{l}\text { Konsumen mengharapkan diskon } \\
\text { minimal } 1 \text { bulan sekali }\end{array}$ \\
\hline
\end{tabular}

Analisis Regresi Logistik Kesediaan Membayar Konsumen

WTP memiliki pengertian berupa harga maksimum dari suatu barang yang ingin dibeli oleh konsumen pada waktu tertentu (Zhao dan Kling, 2004). Pengukuran nilai WTP menggunakan metode stared preference. Metode ini digunakan untuk mengukur kesediaan membayar responden dengan menanyakan berapa jumlah yang responden bersedia untuk membayar. Penilaian responden terhadap situasi tertentu dapat 
diketahui dengan memberikan pernyataan yang dapat dinilai responden baik secara langsung maupun melalui ranking, rating, atau choice. Dengan nilai WTP masingmasing responden yaitu berupa nilai maksimum rupiah yang bersedia dibayarkan oleh responden untuk mendapatkan nilai rata-rata (mean) dari nilai WTP tersebut dengan rumus:

$$
\mathrm{MWTP}=\underline{1} \sum \mathrm{n} \mathrm{i}=1 \quad \mathrm{WTPi}
$$

Keterangan: MWTP (Rata-rata WTP); n (Ukuran sampel); WTPi (Nilai WTP maksimum respinden ke-i).

Willingness to Pay (WTP) konsumen Kota Bogor terkait dengan produk yang diproduksi oleh PT Unilever, yaitu berupa minuman sari buah asli Buavita Royale ini selanjutnya akan dikaji lebih lanjut dengan analisis regresi berganda dengan program Microsoft Excel dan Minitab for Windows Realase 14 guna mencari hubungan antara faktor-faktor yang memengaruhi WTP dengan besaran WTP-nya dalam sebuah persamaan matematis. Analisis lebih lanjut dilakukan dengan wawancara dan pertanyaan terbuka kepada responden terkait sikap responden terhadap produk Buavita Royale. Schmid (2005) dalam Firdaus (2011) analisis regresi logistik atau yang dikenal dengan logit merupakan bagian dari analisis regresi. Analisis ini digunakan untuk mengkaji hubungan peubah (-peubah) penjelas (x) terhadap peubah respon (y) melalui model persamaan matematis tertentu. Apabila peubah y merupakan peubah dengan data numerik maka dapat menggunakan metode kuadrat terkecil biasa, namun dalam beberapa kondisi tertentu, peubah y dapat berupa peubah kategorik. Apabila peubah y berupa peubah kategorik maka analisis yang digunakan adalah analisis logistik berikut:

$$
\operatorname{Logit}(\mathrm{Y})=\ln =(\mathrm{y} /(1-\mathrm{y}))
$$

Dengan y merupakan peluang munculnya kejadian kategori sukses dari peubah respon untuk orang ke-i. Kategori yang merupakan sukses secara umum merupakan kategori yang menjadi perhatian dalam penelitian. Hal ini menyebabkan model yang digunakan dalam analsisi regresi logistik adalah sebagai berikut:

$$
\operatorname{Logit}(\mathrm{Y})=\beta 0+\beta 1 \mathrm{X} 1
$$

Keterangan: Logit (y) (nilai transformasi logit untuk peluang kejadian berhasil atau sukses); $\beta 0$ (intersep model garis regresi); $\beta 1$ (slope model garis regresi); $\mathrm{X} 1$ (peubah penjelas).
Model analisa regresi logistik digunakan dalam penelitian ini dikarenakan variabel dependen yang akan diteliti merupakan peubah kategorik. Variabel independen yang diperkirakan akan mempengaruhi kesediaan konsumen untuk membayar adalah variabel jenis kelamin, pendidikan, status pernikahan, pekerjaan, pendapatan, jumlah anggota keluarga, sikap konsumen, keyakinan terhadap produk. Sehingga, model regresi logistik dalam penelitian ini adalah:

$$
\begin{aligned}
\operatorname{Logit}(\mathrm{pi})= & \beta_{0}+\beta_{1} \mathrm{X}_{1}+\beta_{2} \mathrm{X}_{2}+\beta_{3} \mathrm{X}_{3}+\beta_{4} \mathrm{X}_{4}+\beta_{5} \mathrm{X}_{5}+\beta_{6} \mathrm{X}_{6} \\
& +\beta_{7} \mathrm{X}_{7}+\beta_{8} \mathrm{X}_{8}
\end{aligned}
$$

Keterangan: Logit (pi) (Kesediaan konsumen untuk membayar (Ya/Tidak)); $\beta 0$ (Intercept); $\beta 1$... $\beta 9$ (Slope model regresi); X1 (Konsumen membeli Buavita Royale karena manfaat yang diberikan ("1" bersedia, "0" tidak bersedia)); X2 (Perspektif konsumen mengenai kebutuhan RTD Buavita Royale karena bekerja ("1" ya, "0" tidak)); X3 (Harga Buavita Royale ("1" murah, "0" mahal)); X4 (Tingkat kesukaan anggota keluarga terhadap produk Buavita Royale ("1" suka, "0" tidak suka)); X5 (Tingkat kebutuhan Buavita Royale dikarenakan usia ("1" butuh, " 0 " tidak butuh)); X6 (Pengetahuan konsumen terhadap produk Buavita Royale dilihat berdasarkan tingkat pendidikan yang tinggi ("1" setuju, "0" tidak setuju));X7 (Sikap konsumen terhadap produk Buavita Royale ("1" positif, "0" negatif)); X8 (Tingkat keyakinan konsumen terhadap produk Buavita Royale karena manfaat yang diberikan sangat baik jika dikonsumsi rutin ("1" yakin, "0" tidak yakin)).

\section{HASIL}

\section{Sikap Konsumen terhadap produk Buavita Royale}

Pada dasarnya, citra atau reputasi merek suatu perusahaan turut berpengaruh pada reputasi perusahaan itu sendiri sehingga menunjukan sikap konsumen terhadap suatu produk (Berry, 2000). Syah (2013) menyatakan reputasi perusahaan mempunyai pengaruh yang kuat terhadap sikap keputusan untuk membeli suatu produk. Selain itu, hal ini mengindikasikan reputasi perusahaan mempunyai pengaruh terhadap sikap loyalitas konsumen. Iswadi dan Tiasity (2015) mengungkapkan reputasi perusahaan yang baik mempengaruhi sikap loyalitas kepercayaan konsumen terhadap apapun produk yang dihasilkan perusahaan. 
Sikap adalah kecenderungan untuk suka atau tidak suka terhadap sesuatu seperti ide, orang, atau perilaku (Blackwell et al. 2006). Berdasarkan hasil dari analisis multiatribut Fishbein dari atribut variabel yang diteliti, dengan mengurutkan atribut yang dianggap penting dan dikalikan dengan atribut yang mendapat penilaian kepercayaan konsumen. Hasil dari atribut harga murah didominasi oleh produk Buavita Royale $(16,72)$ dibandingkan dengan Buavita Classic $(15,08)$. Konsumen memandang bahwa harga dari Buavita Royale sudah cukup murah apabila dilihat dari manfaat yang diberikan Buavita Royale yaitu tidak hanya manfaat dari kandungan buah saja melainkan manfaat yang terkandung dalam sayuran, seperti terlihat pada Tabel 2.

Pada Tabel 2 dapat disimpulkan bahwa meskipun terdapat beberapa atribut yang tertinggi didominasi oleh Buavita Royale. Secara keseluruhan hasil dari kepercayaan dan dikalikan dengan evaluasi konsumen tertinggi terdapat pada produk Buavita Classic $(293,40)$ sedangkan hasil dari Buavita Royale $(291,37)$ lebih rendah. Selisih dari nilai tersebut tidak terlalu jauh, sehingga tidak menutup kemungkinan bahwa konsumen tetap ingin membeli dan mengkonsumsi Buavita Royale.

\section{Strategi dengan pendekatan Importance Performance Analysis (IPA)}

Hasil dari analisis IPA dengan menggunakan diagram kartesius sebagaimana terlihat pada Gambar 1. Pada kuadran I menunjukan bahwa atribut tersebut menunjukan kinerja yang tinggi namun tingkat kepentingannya rendah, sedangkan pada kuadran II menunjukan atribut tersebut sudah sangat baik dalam artian memiliki tingkat kepentingan yang tinggi serta kinerja yang tinggi pula. Kuadran III menunjukan bahwa atribut tersebut memiliki tingkat kinerja yang rendah dan tingkat kepentingan rendah, sedangkan kuadran IV menunjukan tingkat kinerja yang tinggi namun tingkat kepentingannya rendah . Hal ini menunjukan bahwa dari hasil penelitian, atribut-atribut yang perlu diperbaiki oleh perusahaan terdapat pada kuadran I.

Tabel 2. Skor rata-rata tingkat kepentingan dan tingkat kinerja produk buavita

\begin{tabular}{|c|c|c|c|c|c|}
\hline \multirow{3}{*}{ Kode } & \multirow{3}{*}{ Atribut Variabel } & \multicolumn{4}{|c|}{ Skor Kepercayaan (bi) } \\
\hline & & \multicolumn{2}{|c|}{ Royale } & \multicolumn{2}{|c|}{ Classic } \\
\hline & & bi & bi.ei & bi & bi.ei \\
\hline X19 & Harga murah & 3,69 & 16,72 & 3,33 & 15,08 \\
\hline $\mathrm{X} 16$ & Mudah ditemukan dipasaran & 3,08 & 13,86 & 4,21 & 18,95 \\
\hline $\mathrm{X} 4$ & Bermanfaat bagi kesehatan tubuh & 4,04 & 18,06 & 3,66 & 16,36 \\
\hline $\mathrm{X} 1$ & Desain kemasan sangat menarik & 3,93 & 17,25 & 3,16 & 13,87 \\
\hline $\mathrm{X} 20$ & Konsumen mengharapkan discount minimal 1 bulan sekali & 4,13 & 17,72 & 4,04 & 17,33 \\
\hline $\mathrm{X} 7$ & Manfaat berpengaruh positif bagi tubuh & 4,04 & 17,21 & 3,68 & 15,68 \\
\hline $\mathrm{X} 8$ & Merek popular bagi siapapun & 3,07 & 13,08 & 4,18 & 17,81 \\
\hline $\mathrm{X} 14$ & Rasa enak sekali & 4,05 & 17,01 & 4,04 & 16,97 \\
\hline X6 & Dapat melepas dahaga & 3,87 & 15,91 & 3,97 & 16,32 \\
\hline $\mathrm{X} 3$ & Warna kemasan sangat menarik & 4,12 & 16,89 & 3,43 & 14,06 \\
\hline $\mathrm{X} 11$ & Motivasi PT Unilever sangat jelas dan visioner & 3,92 & 15,80 & 3,92 & 15,80 \\
\hline $\mathrm{X} 10$ & Reputasi PT Unilever sangat baik & 4,21 & 16,84 & 4,21 & 16,84 \\
\hline $\mathrm{X} 18$ & $\begin{array}{l}\text { Konsumen bisa dengan cepat menemukan produk karena dekat dengan } \\
\text { rumah/kantor }\end{array}$ & 3,20 & 12,74 & 3,93 & 15,64 \\
\hline X9 & Merek mempunyai reputasi yang sangat baik & 3,51 & 13,76 & 3,51 & 13,76 \\
\hline $\mathrm{X} 12$ & Konsumen memiliki pengalaman yang menyenangkan & 3,71 & 14,43 & 3,51 & 13,65 \\
\hline $\mathrm{X} 15$ & Besarnya intensitas promosi & 2,47 & 9,51 & 3,22 & 12,40 \\
\hline $\mathrm{X} 2$ & Logo mudah ditemukan & 3,82 & 14,02 & 3,53 & 12,96 \\
\hline $\mathrm{X} 13$ & Varian rasa yang terlalu sedikit & 3,08 & 11,15 & 2,93 & 10,61 \\
\hline $\mathrm{X} 17$ & Konsumen memiliki waktu untuk membeli & 3,18 & 9,95 & 3,29 & 10,30 \\
\hline \multirow[t]{2}{*}{$\mathrm{X} 5$} & Manfaat yang didapat berbentuk intangible & 3,67 & 9,47 & 3,50 & 9,03 \\
\hline & Total & 72,79 & 291,37 & 73,25 & 293,40 \\
\hline
\end{tabular}

*Nilai sudah diurutkan berdasarkan nilai tertinggi ke terendah 


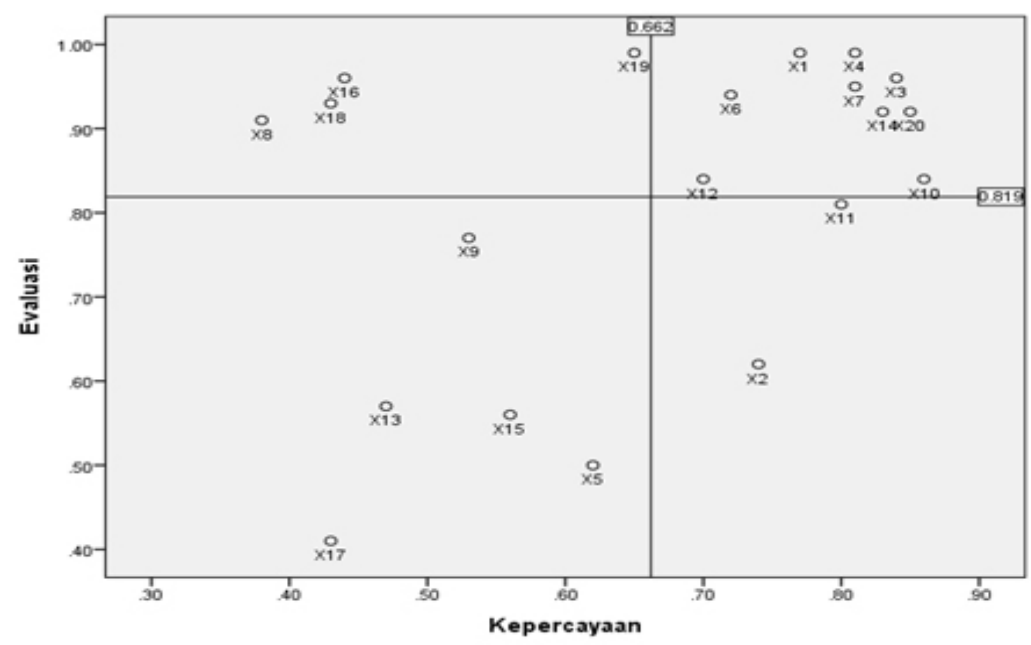

Keterangan:
Kuadran I (Prioritas utama)
X8 $\quad$ : Merek popular bagi siapapun
X16 $\quad$ Mudah ditemukan dipasaran
X18 $\quad$ Konsumen bisa dengan cepat

menemukan produk karena dekat
dengan rumah/kantor
X19 : harga murah

\author{
Kuadran II (Pertahankan prestasi) \\ $\mathrm{X} 1 \quad$ : Desain kemasan sangat menarik \\ X3 : Warna kemasan menarik \\ X4 : Bermanfaat bagi kesehatan tubuh \\ X6 : Dapat melepas dahaga \\ X7 : Manfaat berpengaruh positif terhadap tubuh \\ X10 : Reputasi PT Unilever Tbk sangat baik \\ X12 : Konsumen memiliki pengalaman yang \\ menyenangkan \\ X14 : Rasa enak sekali \\ X20 : Konsumen mengharapkan discount minimal 1 bulan sekali \\ Kuadran IV (Berlebihan) \\ $\mathrm{X} 2$ : Logo mudah ditemukan \\ X11 : Motivasi PT Unilever sangat \\ jelas dan visioner
}

\section{Faktor-faktor yang memengaruhi Willingness to Buy}

Berdasarkan rumus analisis logistik, hasil output untuk willingness to buy terhadap produk Buavita Royale. Semua variabel independen nilai P value uji wald (Sig) $<0,05$, artinya masing-masing variabel mempunyai pengaruh parsial yang signifikan terhadap Y di dalam model, sebagaimanna terlihat pada Tabel 3. Tabel ini menunjukan variabel yang berpengaruh signifikan terhadap keinginan konsumen untuk membayar produk Buavita Royale adalah jenis kelamin (X1), harga produk Buavita Royale yang murah (X4), dan sikap konsumen yang positif terhadap produk Buavita Royale (X8). Besarnya pengaruh variabel ditunjukan dengan nilai exp (B) atau yang dikenal dengan odds ratio (OR).
Variabel jenis kelamin (X1) memiliki nilai rasio odd sebesar 0,387, artinya laki-laki cenderung lebih sering membeli produk Buavita Royale dibandingkan dengan wanita. Maka, dalam penelitian ini tidak benar bahwa wanita cenderung membeli produk Buavita Royale. Selanjutnya, variabel sikap konsumen terhadap produk Buavita Royale positif (X8) memiliki nilai rasio odd sebesar 3,845. Artinya, sikap positif konsumen terhadap produk Buavita Royale terbukti meningkatkan kesediaan konsumen untuk membayar dan membeli produk Buavita Royale. Variabel harga yang murah (X4) memiliki nilai rasio odd sebesar 15,887. Artinya, harga produk Buavita Royale yang beredar dipasaran saat ini tidak menjadi persoalan bagi responden sehingga harga produk saat ini cenderung meningkatkan kesediaan konsumen untuk membayar dan membeli produk Buavita Royale. Hasil uji statistik pun menemukan perbedaan variabel yang berpengaruh terhadap produk Buavita Royale ukuran $1.000 \mathrm{ml}$ (Tabel 4). 
Hasil uji pendugaan parameter produk Buavita Royale ukuran kemasan $1000 \mathrm{ml}$ ditemukan bahwa variabel yang berpengaruh adalah variabel jenis kelamin (X1) berpengaruh signifikan terhadap kesediaan membayar konsumen, selain itu variabel konsumen membutuhkan RTD Buavita Royale dikarenakan bekerja memiliki tingkat kepercayaan 95\% sehingga secara signifikan berpengaruh terhadap kesediaan membayar dan membeli produk Buavita Royale ukuran $1000 \mathrm{ml}$. Sementara itu, variabel harga produk yang murah (X4) pada tingkat kepercayaan 99\% secara signifikan berpengaruh terhadap kesediaan membayar produk. Selanjutnya, variabel konsumen memiliki sikap yang positif terhadap produk Buavita Royale pada tingkat kepercayaan 90\% secara signifikan berpengaruh terhadap kesediaan membayar.

\section{Nilai maksimum Willingness to Pay Produk Buavita Royale}

PT Unilever memerlukan strategi penempatan harga yang sesuai bagi produk Buavita Royale, karena harga merupakan faktor paling penting dalam menentukan kepuasan pelanggan (Virvilaite et al. 2009). Hasil nilai rataan willingness to pay konsumen terhadap produk Buavita Royale (Tabel 5) adalah sebesar Rp8.226 untuk ukuran $250 \mathrm{ml}$. Nilai ini lebih besar dibandingkan dengan harga yang beredar dipasaran yaitu sebesar Rp7.200. Hasil penelitian menunjukan bahwa responden bersedia membayar lebih untuk produk Buavita Royale dilihat dari manfaat dan kandungan vitamin yang lengkap dalam satu kemasan yang siap untuk langsung dikonsumsi.

Tabel 3. Pendugaan parameter Buavita Royale ukuran $250 \mathrm{ml}$

\begin{tabular}{cccccccccc}
\hline & & & & & & & \multicolumn{3}{c}{$95.0 \%$ C.I for EXP (B) } \\
\hline & & B & S.E & Wald & df & Sig. & Exp (B) & Lower & Upper \\
\hline Step1 $^{\text {a }}$ & X1 &,- 950 &, 421 & 5,100 & 1 &, 024 &, 387 &, 170 &, 882 \\
& X2 &, 078 &, 526 &, 022 & 1 &, 881 & 1,082 &, 386 & 3,030 \\
& X3 &,- 187 &, 387 &, 232 & 1 &, 630 &, 830 &, 388 & 1,773 \\
& X4 & 1,347 &, 398 & 11,478 & 1 &, 001 & 3,845 & 1,764 & 8,382 \\
& X5 &,- 432 &, 474 &, 832 & 1 &, 362 &, 649 &, 256 & 1,644 \\
& X6 &,- 030 &, 425 &, 005 & 1 &, 944 &, 971 &, 422 & 2,234 \\
X7 &, 365 &, 749 &, 237 & 1 &, 626 & 1,440 &, 332 & 6,249 \\
& X8 & $-2,766$ & 1,158 & 5,708 & 1 &, 017 & 15,887 & 1,643 & 153,599 \\
\hline
\end{tabular}

Tabel 4. Pendugaan parameter Buavita Royale ukuran $1.000 \mathrm{ml}$

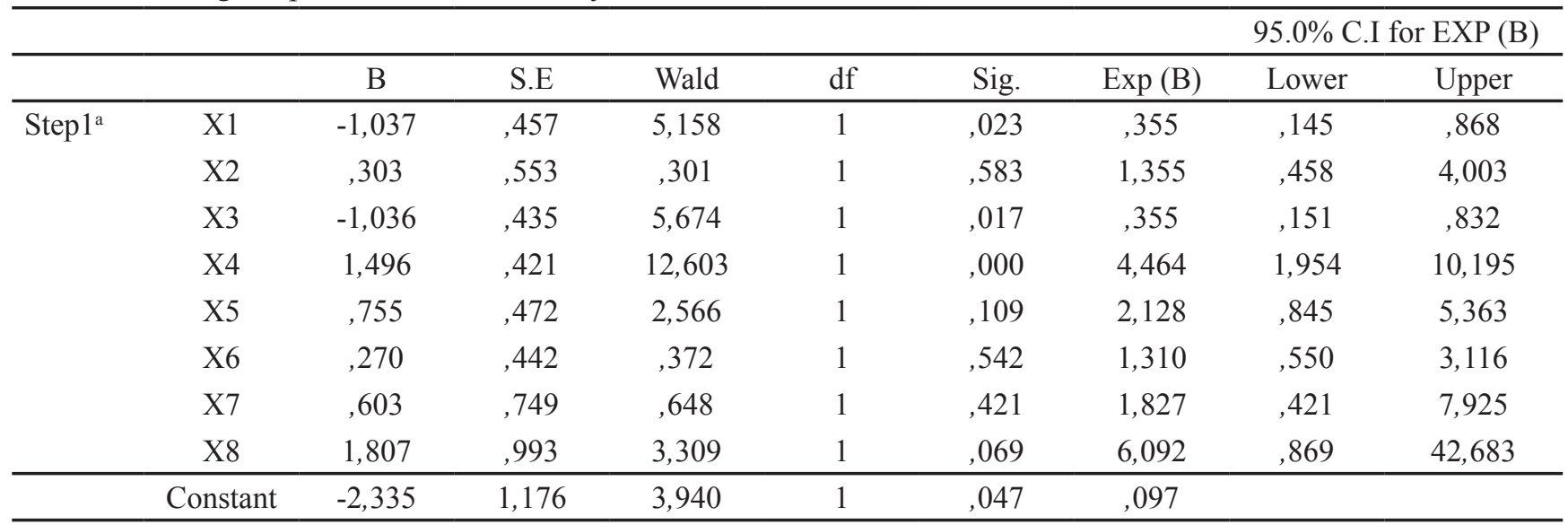


Pada Tabel 6 terlihat bahwa harga pada produk Buavita Royale yang beredar dipasaran untuk ukuran 1 liter kurang lebih memiliki kisaran harga Rp33.600 sampai dengan Rp34.900. Hasil penelitian menunjukkan bahwa dari 180 responden, 47 responden bersedia untuk memberikan harga untuk produk Buavita Royale ukuran 1 liter sebesar Rp27.000. Sebesar 17.8\% atau sebanyak 32 responden menilai bahwa harga yang akan diberikan sebesar Rp29.900.

\section{Implikasi Manajerial}

Implikasi manajerial yang dapat diaplikasikan oleh PT Unilever Indonesia adalah beberapa atribut yang dianggap penting oleh konsumen dan memiliki penilaian kinerja yang sangat baik pula sehingga PT Unilever Tbk harus tetap mempertahankan beberapa atribut-atribut yang sudah diteliti dalam penelitian ini, diantaranya: 1) Desain kemasan sangat menarik; 2)
Warna kemasan sangat menarik; 3) Bermanfaat bagi kesehatan tubuh; 4) Dapat melepas dahaga; 5) Manfaat berpengaruh positif terhadap tubuh; 6) Reputasi PT Unilever Tbk sangat baik; 7) Konsumen memiliki pengalaman yang menyenangkan; 8) Rasa enak sekali; dan 9) Konsumen mengharapkan discount minimal 1 bulan sekali.

Produk Buavita Royale memiliki beberapa atribut yang dianggap penting namun kinerjanya masih dianggap kurang oleh konsumen sehingga perlu melakukan perbaikan untuk meningkatkan produktivitas dari produk Buavita Royale. Atribut-atribut tersebut adalah: 1) Merek popular bagi siapapun; 2) Mudah ditemukan dipasaran; 3) Konsumen bisa dengan cepat menemukan produk karena dekat dengan rumah/ kantor; 4) Harga murah. Selain itu, PT Unilever Tbk dapat menciptakan Corporate Social Marketing (CSM) kepada konsumen.

Tabel 5. Distribusi harga produk buavita royale ukuran kemasan $250 \mathrm{ml}$

\begin{tabular}{ccc}
\hline Nilai WTP $(\mathrm{Rp})$ & Jumlah Responden (Orang) & Mean WTP (Rp/Orang) \\
\hline 7.200 & 40 & 1.600 \\
8.100 & 31 & 2.881 \\
8.500 & 61 & 939 \\
8.900 & 19 & 633 \\
9.500 & 12 & 778 \\
10.000 & 14 & 8.226 \\
\hline Lainnya & 3 &
\end{tabular}

Tabel 6. Distribusi harga produk buavita royale ukuran kemasan $1 \mathrm{~L}$

\begin{tabular}{ccc}
\hline Nilai WTP $(\mathrm{Rp})$ & Jumlah Responden (Orang) & Mean WTP (Rp/Orang) \\
\hline 27.000 & 47 & 7.050 \\
29.500 & 16 & 2.622 \\
29.900 & 32 & 5.316 \\
31.000 & 30 & 5.167 \\
33.500 & 28 & 5.211 \\
34.900 & 24 & 4.653 \\
\hline Lainnya & 3 & 30.019 \\
\hline Jumlah & 180 &
\end{tabular}




\section{KESIMPULAN DAN SARAN}

\section{Kesimpulan}

Simpulan dalam penelitian ini yaitu pada sikap konsumen diukur dengan metode multiatribut Fishbein ditemukan bahwa hasil dari atribut kepercayaan konsumen dan dikalikan dengan atribut evaluasi konsumen mendapatkan penilaian 291.37 sehingga tidak menutup kemungkinan bahwa konsumen tetap ingin mengonsumsi, membeli dan bersedia untuk membayar produk Buavita Royale. Strategi yang dapat dilakukan perusahaan melalui pendekatan IPA berdasarkan dari atribut yang diteliti bahwa dari segi desain kemasan, manfaat, rasa, pengalaman konsumen dan reputasi PT Unilever sudah sangat baik. Atributyang dapat diperbaiki oleh Buavita Royale adalah pengenalan akan merek produk, ketersediaan dipasaran, serta harga yang telah beredar dipasaran. Faktor-faktor yang memengaruhi WTB konsumen terhadap produk Buavita Royale adalah harga produk yang beredar dipasaran saat ini tidak menjadi persoalan bagi responden sehingga harga produk cenderung meningkatkan kesediaan konsumen untuk membeli. Konsumen memiliki sikap yang positif terhadap produk Buavita Royale. Besarnya nilai maksimum WTP produk Buavita Royale kemasan $250 \mathrm{ml}$ ditemukan sebanyak $33,9 \%$ responden bersedia membayar Rp8.500 sedangkan harga yang beredar dipasaran sebesar Rp7.200, hal ini menunjukan bahwa konsumen bersedia membayar lebih dengan nilai maksimum Rp8.500 dari nilai rata-rata Rp8.226. Selain itu besarnya nilai maksimum WTP produk Buavita Royale kemasan $1000 \mathrm{ml}$ ditemukan sebanyak 26.1\% bersedia membayar Rp27.000 sedangkan harga yang beredar dipasaran memiliki kisaran harga Rp33.600Rp34.900, sehingga dalam hal ini untuk kemasan Buavita Royale ukuran $1.000 \mathrm{ml}$ nilai rata-rata yang bersedia konsumen bayarkan adalah sebesar Rp27.000 sampai dengan Rp31.000 dengan harga maksimum rata-rata $\mathrm{Rp} 30.019$.

\section{Saran}

Saran untuk penelitian selanjutnya dari penelitian ini adalah penelitian ini dilakukan hanya berfokus terhadap variabel dan indikator yang terdapat pada satu merek saja tanpa membandingkan dengan merek produk sejenis. Untuk lebih mendalami sikap dan WTP konsumen dapat diteliti dengan membandingkannya dengan merek produk sejenis dengan Buavita. Disarankan penelitian selanjutnya dapat meneliti sikap dan keinginan membayar lebih konsumen dengan membandingkan dengan merek lainnya. Saran untuk penelitian selanjutnya diharapkan dapat melakukan penelitian dengan menggunakan variabel-variabel lainnya yang membentuk WTP.

\section{DAFTAR PUSTAKA}

Andreea R, Ion. 2015. Fruits and vegetables in Romania: better understand consumers' preferences [ulasan]. Bucharest: The Research Institute for Agriculture Economy and Rural Development (ICEADR).

Anselmsson J, Johansson U, Bondesson N. 2014. Brand image and customers' willingness to pay a price premium for food brands. Journal of Product and Brand Management 23(2):90-102.

Berry LL. 2000. Cultivating service brand equity. Journal the Academy of Marketing Science 28(1):128-137.

Blackwell RD. Souza C, Miniard P, Engel JF. 2006. Consumer Behaviour: An Asia Pascific Approach. Sidney: Cengage Learning Australia Pty Limited.

[BPS] Badan Pusat Statistik. 2014. Rata-rata Konsumsi per Kapita Seminggu Beberapa Macam Bahan Makanan Penting. Jakarta: BPS.

DiazFJ, Pleite FM, Paz JM, Garcia PG. 2012. Consumer knowledge, consumption, and willingness to pay for organic tomatoes. Journal of British Food 114(3):318-334.

Firdaus M. 2011. Seri Metode Kuantitatif: Aplikasi Ekonometrika untuk Data Panel. Bogor: IPB Press.

Hermawan A, Yusran HL. 2015. The effects of dental atmospherics on patient's emotion and behavioural intentions. Ekonomické Rozhl'ady 44(1):44-52.

Iswadi A, dan Tiastity R. 2015. Analisis pengaruh reputasi perusahaan dan kepercayaan pelanggan terhadap loyalitas pelanggan dengan kualitas pelayanan sebagai variabel moderasi. Ekonomi dan Kewirausahaan 15(2):217-226.

Kalashami M, Heydari M, Kazaerani H. 2012. Investigasting consumer's WTP for organic chicken in Iran. International Agricultural Management and Development 2(4):235-241.

Kristanto, Paulus L. 2011. Psikologi Pemasaran: Integrasi Ilmu Psikologi dalam Kegiatan Pemasaran. Yogyakarta: CAPS. 
Laroche M, Bergeron J, Barbaru-Forleo G. 2001. Targeting consumers who are willing to pay more for environmentally friendly products. Journal of Consumer Marketing 18(6): 503-520.

Mowen J, Michael M. 2002. Perilaku Konsumen. Jakarta: Erlangga.

Narine L, Ganpat W, Seepersad G. 2015. Demand for organic produce: trinidian consumers willingness to pay for organic tomatoes. Agribusiness in Developing and Emerging Economies 5(1):7691.

Robert BSW, Williams SR. 2000. Nutrition Throughout The Life Cycle. Boston: McGraw-Hill.

Rusniati. 2014. Analisis sikap konsumen terhadap produk minuman teh dalam kemasan karton merek teh kotak di Banjarmasin. INTEKNA
14(1):1-10.

Syah TYR. 2013. Perbedaan pengaruh citra merek dan reputasi perusahaan terhadap kualitas produk, nilai pelanggan dan loyalitas pelanggan di pasar bisnis. Ekonomi 4(2):209-226.

Tanner C, Kast SW. 2003. Promoting sustainable consumption: determinants of green purchases by Swiss consumers. Journal of Psychology and Marketing 20(10):883-902.

Virvilaite R, Saladiene V, Skindaras D. 2009. The relationship between price and loyalty in services industry. Engineering Economics (3)55:96-104.

ZhaoJ,KlingCL.2004.Willingnesstopay, compensating variation, and the cost of commitment. Economic Inquiry 42(3):503-517. 